\title{
Quality by Design: Predefined Objected Quality and Quality Risk Management
}

\author{
P.V. Powar *, D. S. Shirode \\ Dr. D. Y. Patil College of Pharmacy, Akurdi Pune 44, India. \\ *Corresponding author's E-mail: priyatama.powar@gmail.com
}

Received: 07-09-2020; Revised: 23-10-2020; Accepted: 30-10-2020; Published on: 15-11-2020.

\begin{abstract}
Quality by Design ( $Q b D)$ is one of the most powerful strategies which act as a part of modern approach to pharmaceutical industry. The quality in the process and product is neither assures just by inspection nor testing the products, the quality should be built in by design. This paper gives idea about the Pharmaceutical Quality by Design (QbD) and describes use of Quality by Design to ensure quality of Pharmaceuticals. The Quality by Design is described and some of its elements identified. Process parameters and quality attributes are identified for each unit operation. Benefits, opportunities and steps involved in Quality by Design of Pharmaceutical products are described. The aim of the pharmaceutical development is to design a quality product and its manufacturing process to consistently deliver the intended performance of the product. It includes the Quality target product profile, critical quality attributes and key aspects of Quality by Design. It also gives comparison between product quality by end product testing and product quality by Quality by Design. The foundation of Quality by Design is ICH Guidelines. It is based on the ICH Guidelines Q8 for pharmaceutical development, Q9 for quality risk management, Q10 for pharmaceutical quality systems. It also gives application of Quality by Design in pharmaceutical development and manufacturing of pharmaceuticals.
\end{abstract}

Keywords: Quality by Design (QbD), critical process parameters (CPP), Quality target product profile (QTPP), Critical quality attributes (CQA).

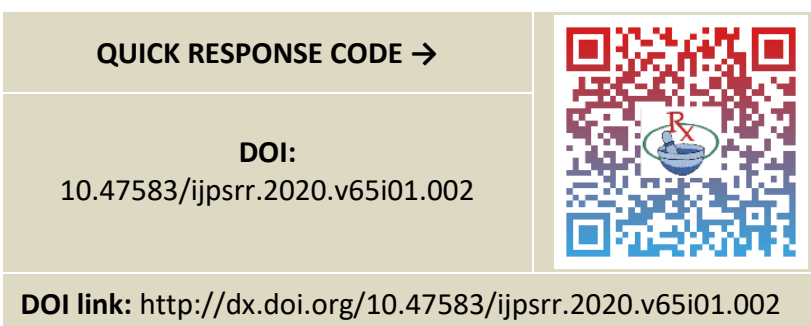

\section{INTRODUCTION}

T

he pharmaceutical Quality by Design (QbD) is a organized approach to improvement that begins with predefined objectives and emphasizes product, process understanding and process control, based on scientific knowledge and quality risk management. Quality means suitability for intended use. Pharmaceutical quality refers to product free of microbial and other contamination, reproducibly delivers the effective therapeutic benefit promised in the label to the patients. Customer or patient satisfaction can be achieved by various ways i.e. features like performance, trust worthiness, robustness, ease of use and service ability have to build in the product and such product should be free from deficiencies. Quality by design approach assures in vitro and In vitro product performance ${ }^{1}$.

Quality activities must try to detect quality problems early enough to allow actions without requiring pacification in cost, schedule or quality of product.

The statistics and knowledge gained from various pharmaceutical studies and manufacturing processes provide a base for scientific understanding to maintain establishment of design space, specification and manufacturing control. Informative data from pharmaceutical development studies can be an origin for quality risk management. Lifecycle management allows making changes in formulation and manufacturing processes during development and providing additional opportunities to gain added knowledge and it further supports establishment of the design space. Design space is planned by the applicant and will undergo regulatory assessment and approval. QbD requires identification of all critical formulation attributes and process parameters which can impact the quality of the finished product. Three fundamental aspects of quality planning as Juran trilogy concept ${ }^{2}$.

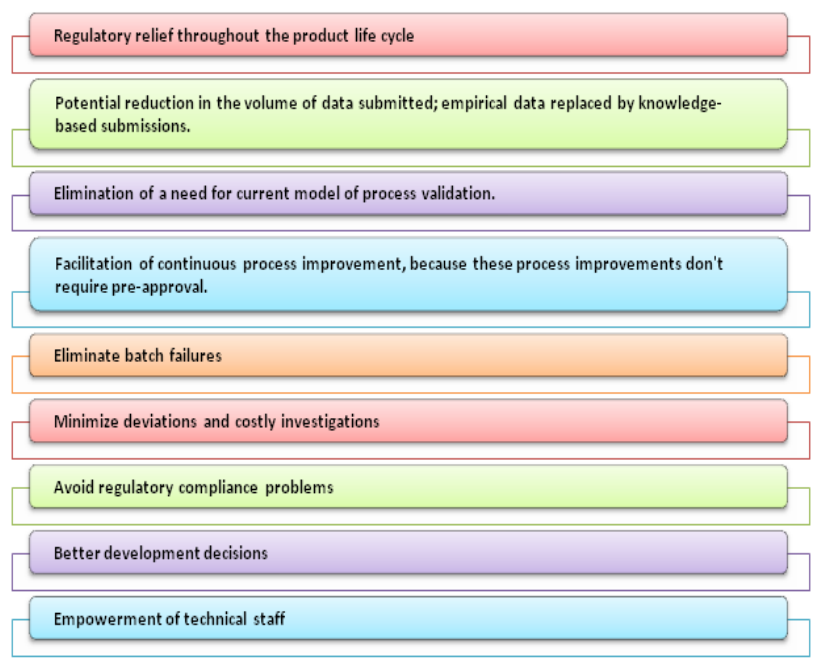

Figure 1: Benefits of quality by design ${ }^{3}$ 
Figure 2 explains the various process in QbD, which will help for understanding and determination of risk factor to improve quality of product.

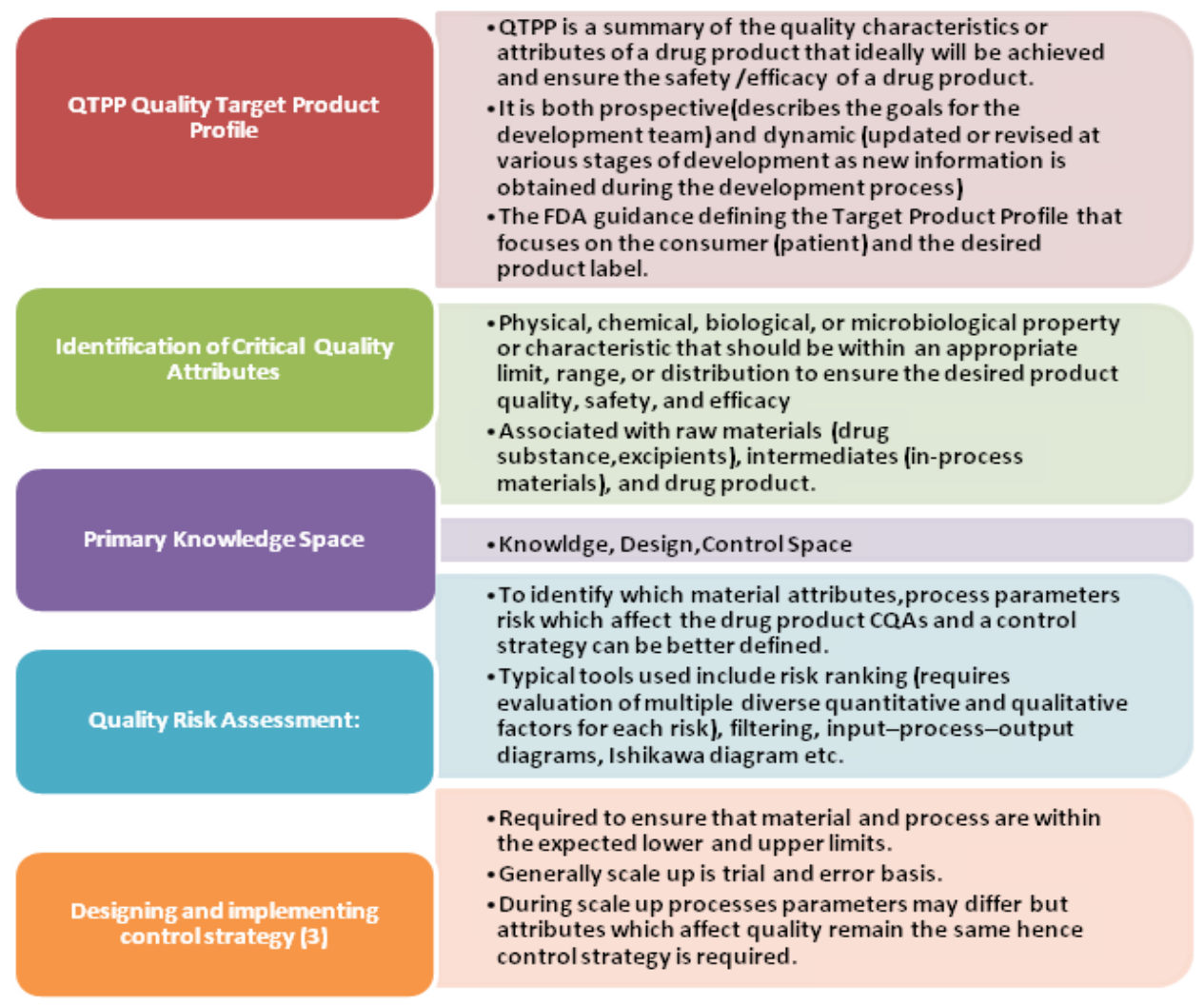

Figure 2: Process of $Q b D^{4-7}$

Diverse variables are monitored for their effect on product quality during manufacturing which are assessed and conclusions will be frame out as a device for QbD. The pharmaceutical product formulation can be constructed based on the data obtained from product development studies. Before conducting the development studies, the Quality Target Product Profile (QTPP) of the product must be resolute and have the final product quality and evaluation steps to be performed for desired product quality. Which includes design space, specifications and manufacturing controls ${ }^{8,9}$.

The purpose of product design and understanding is to develop a robust product which have desired QTPP over the product shelf life. Key elements of product design and understanding include the following 10,11.

Physical (particle size distribution, aqueous solubility as a function of $\mathrm{pH}$, intrinsic dissolution rate, hygroscopicity, and melting point polymorphism, transformation and particle morphology), chemical (pKa, chemical stability in solid state and in solution, as well as photolytic and oxidative stability), and biological characterization (partition coefficient, membrane permeability, and bioavailability.) of the drug substance.
$>$ Identification and selection of excipient type and grade, and knowledge of intrinsic excipient variability: because they carry out functions of

* $\quad$ Aid in the processing of the dosage form during its manufacture eg: binders, disintegrants, fillers (diluents), lubricants, glidants (flow enhancers), compression aids, colors, sweeteners, preservatives, suspending/dispersing agents, pH modifiers/buffers, tonicity agents, film formers/coatings, flavors, and printing inks

* Protect, support, enhance stability, bioavailability, patient acceptability by improving colour, odor, taste. They added in safety limits mentioned in FDA

* Assist in product identification

* Enhance safety, effectiveness, delivery of the drug during storage, use.

$>$ Interactions of drug and excipients

$>$ Optimization of formulation and identification of CMAs of both excipients and drug substance: Which provide Vital data regarding 
* Robustness of the formulation including establishing functional relationships between Critical Quality Attributes and critical material attributes: physical, chemical, biological, or microbiological property or characteristic of an input material that should be within an appropriate limit, range, or distribution to ensure the desired quality of that drug substance, excipient, or in-process material.

* Identification of critical material attributes of drug substance, excipients, in-process materials: which act as input materials including drug substance and excipients.

* Development of control strategies for drug substance and excipients

As shown in below diagram.

\section{QbD tools for Analytical development}

Analytical Quality by Design (AQbD). As per ICH, QbD is defined as "A systematic approach to development that begins with predefined objectives and emphasizes product and process understanding and process control, based on sound science and quality risk management.".

- $\quad$ ICH Q11 : QbD approach for API synthetic process development but there is no specific discussion on AQbD.

- $\quad$ ICH Q3 : explained the consideration of impurities in the API synthetic route.

$A Q b D$ method validation approach is the validation of analytical method over a range of different API batches. It uses both DoE and MODR knowledge for designing method validation for all kinds of API manufacturing changes without revalidation ${ }^{12,13}$.

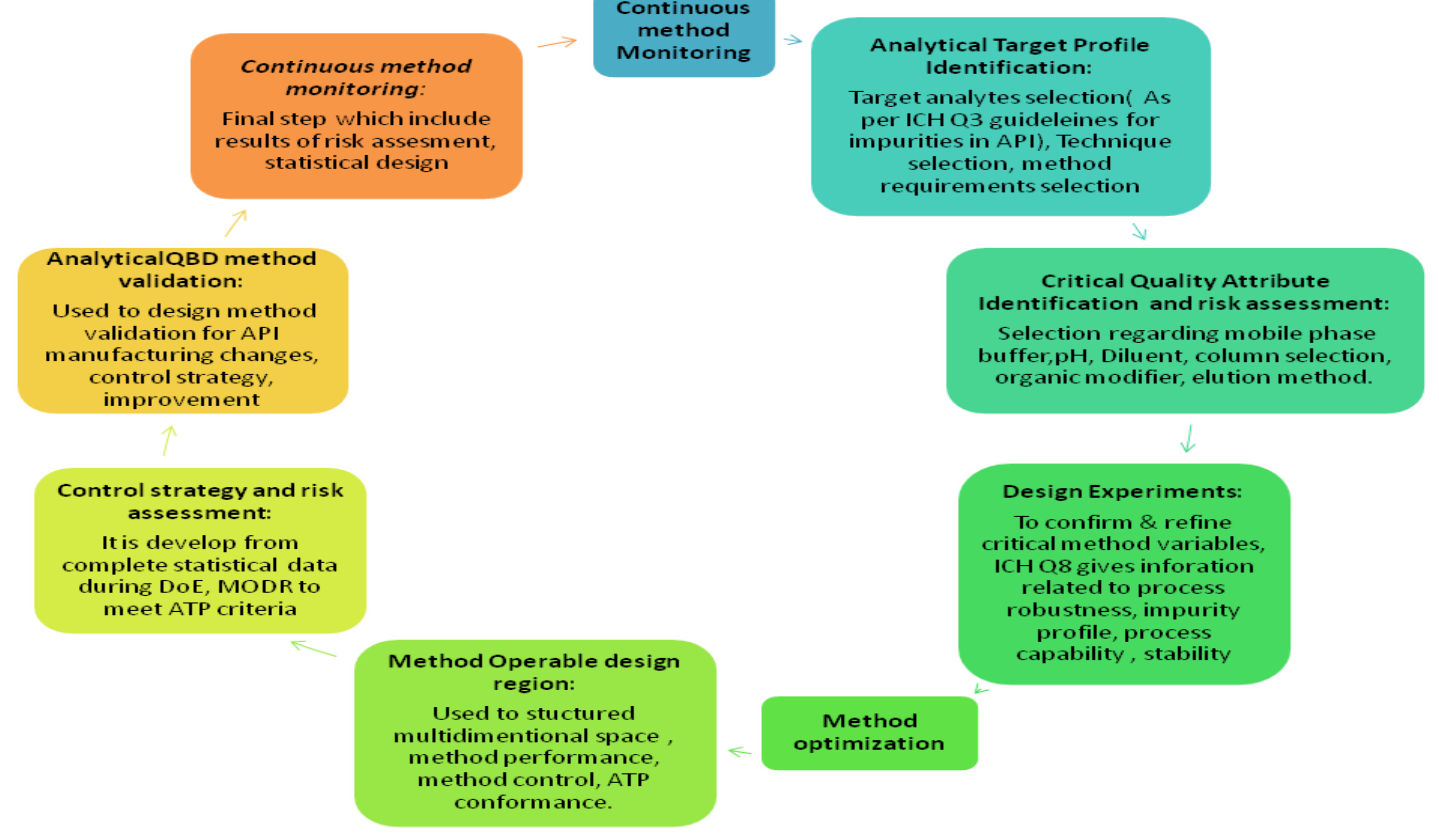

Figure 3: $Q b D$ tools for Analytical development $(A Q b D)^{12,13}$.

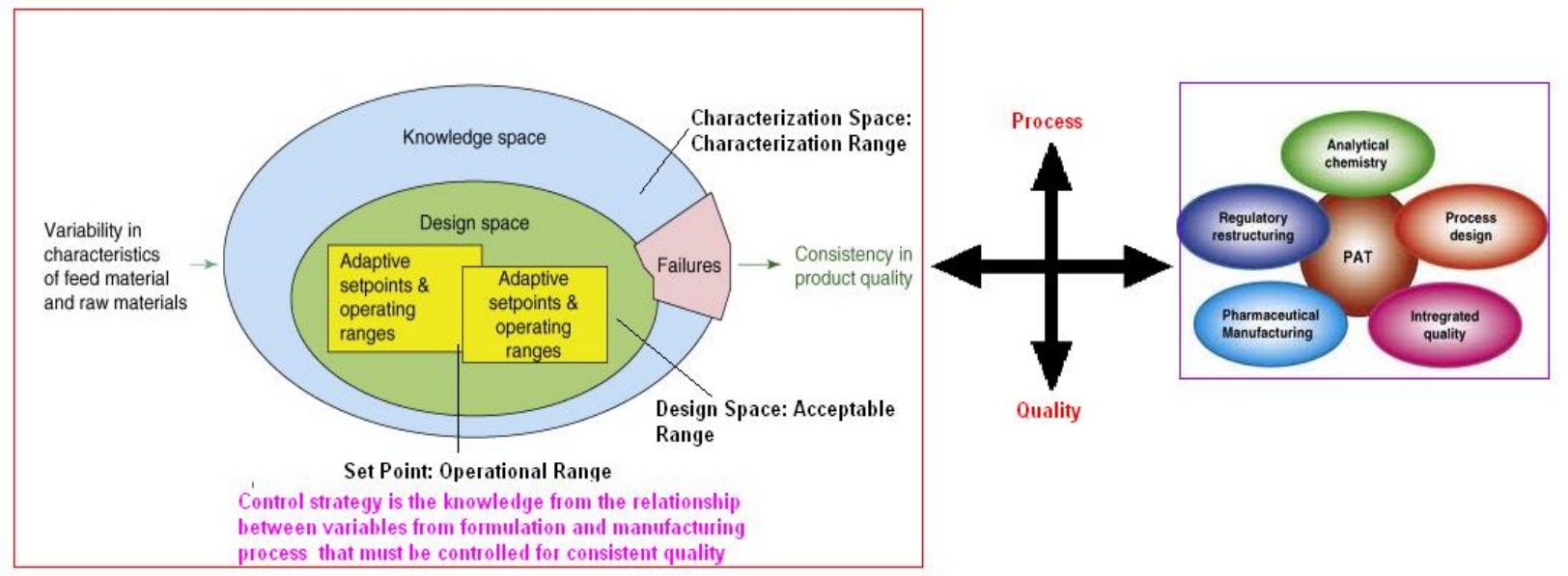

Figure 4: Design Space ${ }^{14}$. 
The design of experiment approach, in which process variables are 'screened' to determine which are vital to the outcome. After which formulation can undergo Optimization with best setting parameter.

Advantages ${ }^{15}$.

- Utilized to evaluate variable of quality target product profile

- Risk- based approach, identification.

- Improve processes help in innovation.

- Less batch failures and more efficient technology transfer

- Robust products and regulatory flexibility

- Innovative process validation approaches.

- Greater product consistency in a product meeting the defined quality attributes.

- Approved, regulatory post approval change requirements will be simplified

- Evaluation of the changes is carried out by quality risk management.

- Design space limits constructive for establishing the acceptance criteria for process validation.
Risk-Based Approach ${ }^{16}$.:

Process Development

- Experimental design (DoE)

- Control Strategy

Process Qualification

- Equipment qualification

- Process performance qualification (PPQ)

Continued Process Verification with Primarily ICH Q8 through Q11

- Q8- Pharmaceutical Development

- Q9- Quality Risk Management

- Q10- Pharmaceutical Quality System

- Q11- Development and Manufacture of Drug Substances

But there may be confusion due to validation and verification process.

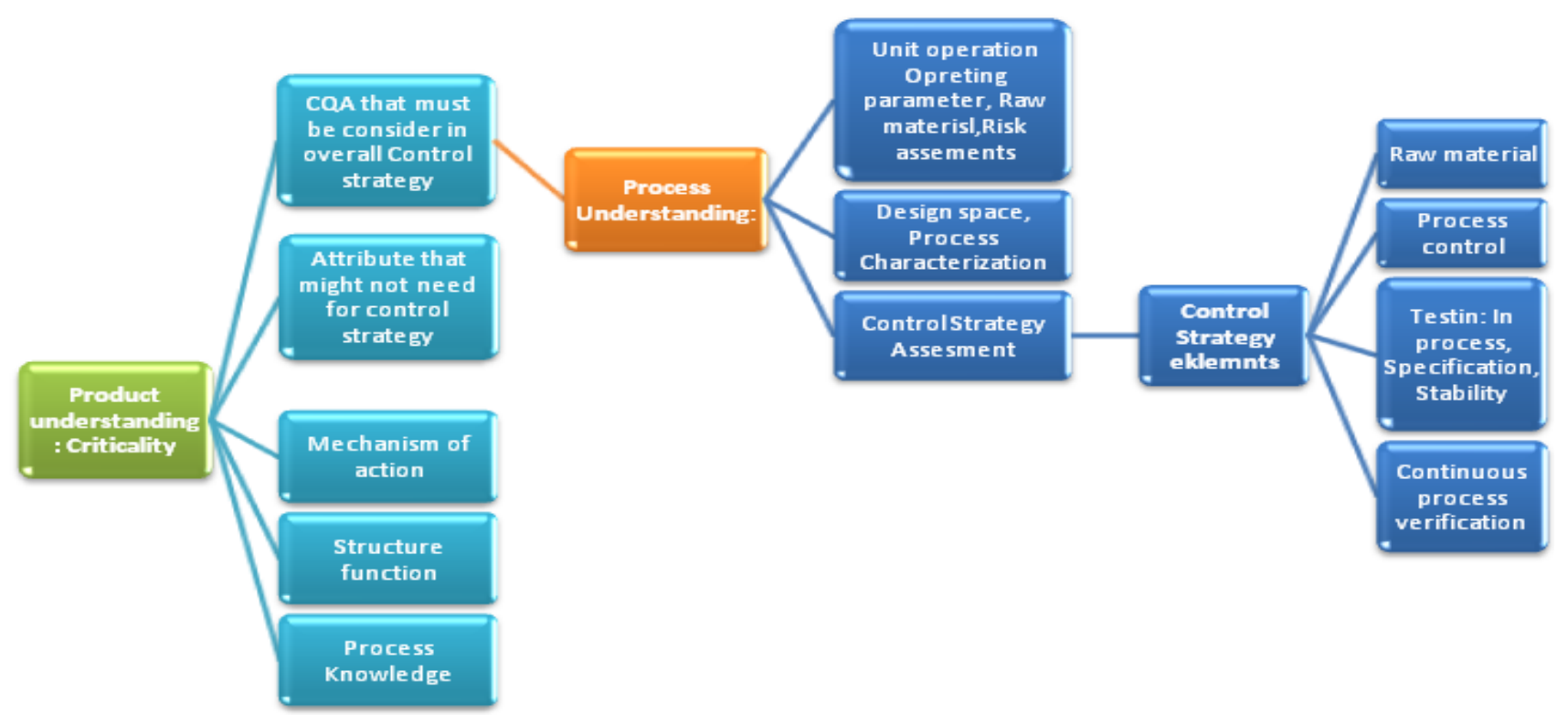

Figure 5: Risk-Based Approach ${ }^{16}$

Some of the most common barriers to adoption include:

- Insufficient understanding of the process and its benefits

- $\quad$ Organizational resistance to change

- Denial of the need ("Our process is under

control")

- $\quad$ Competing priorities

- $\quad$ Lack of resources and expertise in QbD.

Process Development and Risk Assessment: The FDA has given us the green light to assess and manage risk earlier in the drug development cycle. Risk assessment is a valuable science-based process, and the Q8 Pharmaceutical Development guidance encourages the application of scientific approaches and risk management to the development of a product and manufacturing processes $^{17}$.

Q9 Quality Risk Management guidance is an overview of the principles and its applications of risk management ${ }^{18}$

Details of process development risk management explained in Figure No.06.

Methods of risk assessment: As per $\mathrm{ICH}$ guideline Q9 as follows:

- Failure Mode Effects Analysis (FMEA)

- Failure Mode, Effects and Criticality Analysis (FMECA)

○ Fault Tree Analysis (FTA); 
- Hazard Analysis and Critical Control Points (HACCP)

- Hazard Operability Analysis (HAZOP)

- Preliminary Hazard Analysis (PHA)

○ Risk ranking and filtering;

○ Supporting statistical tool

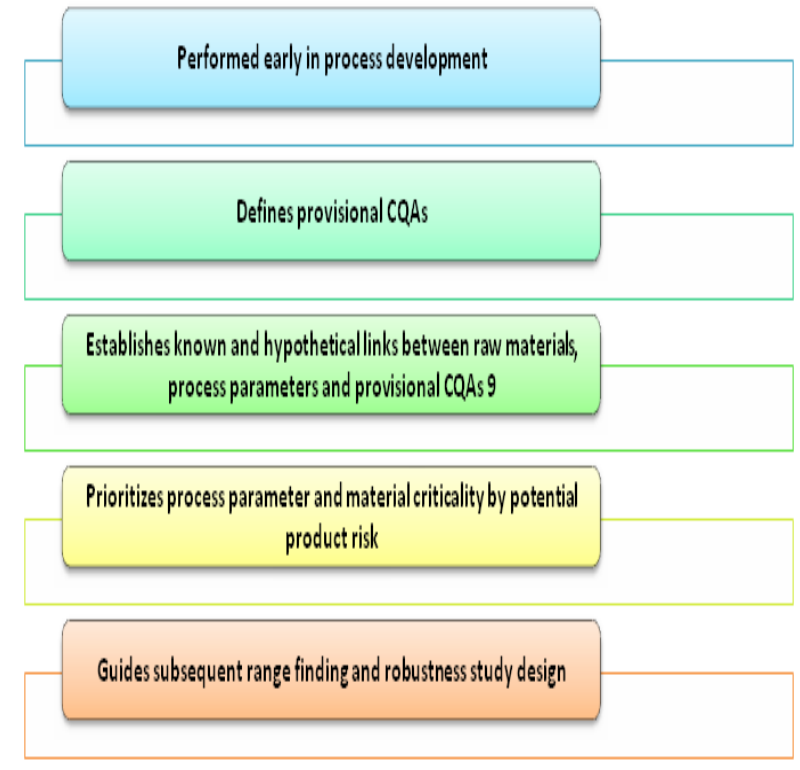

Figure 6: Process Development Risk Assessment

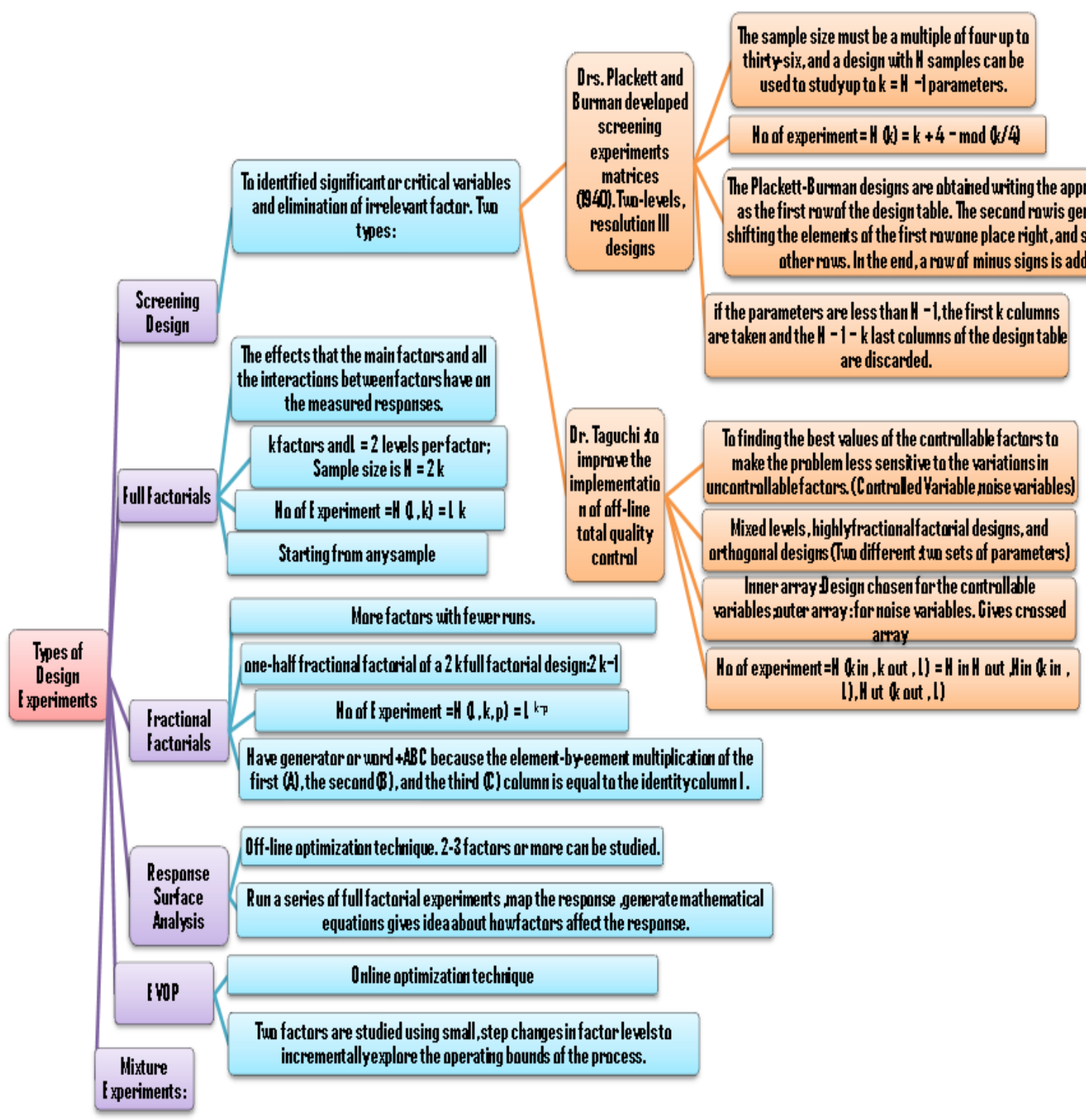

Figure 7: Design of experiment ${ }^{19}$ 
There are some common critical material attributes (CMA) mentioned in Table 1.

Table 1: Critical Material Attributes (CMA)

\begin{tabular}{|c|c|c|}
\hline Parameter type: & Definition & Sensitivity \\
\hline Non-critical process parameter (non- CPP) & Not critical & $\begin{array}{l}\text { - No failure in target product quality profile } \\
\text { (QTPP) observed /predicted in the potential } \\
\text { operating space (POS), and } \\
\text { - No interaction with other parameters in the } \\
\text { proven acceptable range }\end{array}$ \\
\hline $\begin{array}{l}\text { Critical process parameter (CPP): } \\
\text { Any measurable input or output (process state } \\
\text { variable or output material attribute) of a } \\
\text { process step that must be controlled to achieve } \\
\text { the desired product quality and process } \\
\text { consistency }\end{array}$ & $\begin{array}{l}\text { Critical (control } \\
\text { needed to ensure } \\
\text { quality) }\end{array}$ & $\begin{array}{l}\text { - Failure in target product quality profile (QTPP) } \\
\text { observed / predicted in the potential operation } \\
\text { space (POS), } \\
\text { - Interactions with other parameters }\end{array}$ \\
\hline
\end{tabular}

\section{Quality Target Product Profile (QTPP) 20,21,22}

QTPP is a device for setting the calculated groundwork for drug development which includes development planning, clinical, commercial decision making, regulatory agency interactions, risk management etc. The Target Product Profile provides a statement of the overall intent of the drug development program and gives information about the drug at a particular time in development. Usually, the TPP is organized according to the key sections in the drug labelling and links drug development activities to specific concepts intended for inclusion in the drug labeling and focus on labeling concepts, safety and efficacy as follows

- Clinical Pharmacology

- Description

- Indications and Usage

- Contraindications

- Warnings

- Precautions

- $\quad$ Adverse Reactions

- $\quad$ Drug Abuse and Dependence

- Over dosage

- Dosage and Administration

- How Supplied

- Animal Pharmacology and/or Animal Toxicology

- Clinical Studies

Many aspects of the TPP determine the actions of formulation and process development scientists. It is the task of a pharmaceutical scientist to interpret the qualitative TPP into what we define as the target product quality profile (QTPP) for further use in a quality by design process.

Quality target product profile (QTPP) Includes, but not limited to:

- Dosage form

- Route of administration

- Strength

- Release or Delivery of the drug

- Pharmacokinetic characteristics: e.g., dissolution, aerodynamic performance

- Drug product quality characteristics for intended use: e.g., sterility, purity.

\section{Critical Quality Attributes ${ }^{21,22}$}

A Critical Quality Attributes defined as a physical, chemical, biological or microbiological property or characteristics that should be within specified appropriate limit, range, or distribution to ensure the preferred product quality.

Critical Quality Attributes are applicable to for product purity, stability

\section{* Drug substance \\ * Excipients \\ * Intermediates \\ - Drug product}

Critical Quality attributes includes the properties that impart the desired quality, safety, and efficacy.

Table 2: Necessary and Desired elements for QTPP

\section{Necessary Elements}

Quality characteristics: sterility, purity etc. (including specific safety-related impurities where necessary)

Pharmacokinetic characteristics: dissolution etc. Therapeutic effect

Target patient population: neonate, adult etc., clinical diagnosis

Shelf life: temperature, light conditions etc

\section{Desired Elements}

Dosage form: liquid for injection, solid tablet etc.

Route of administration: oral, IV, IM, SC

Clinical setting: self or clinic administration

Primary/secondary packaging: glass or plastic vial/syringe; blister packaging etc 
Table 3: Example of risk filter during initial drug development

\begin{tabular}{|c|c|c|c|c|c|c|c|c|}
\hline $\begin{array}{c}\text { Critical } \\
\text { parameter } \\
\text { factors }\end{array}$ & $\frac{\grave{\vdots}}{\grave{\vdots}}$ & 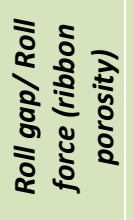 & 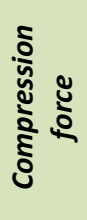 & 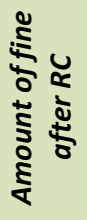 & 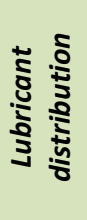 & 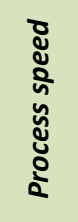 & $\bar{\alpha}$ & 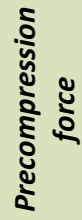 \\
\hline Appearance & Low & Low & High & Low & High & Low & Low & Low \\
\hline Identity & Low & Low & Low & Low & Low & Low & Low & Low \\
\hline Assay & Low & Low & Low & Low & Low & High & Low & Low \\
\hline Impurity & Low & Low & Low & Low & Low & Low & Low & Low \\
\hline Dissolution & High & Low & Low & Low & Low & Low & Low & Low \\
\hline Tablet Hardness & High & High & High & High & High & High & Low & High \\
\hline Friability & High & High & High & High & Low & Low & Low & Low \\
\hline Yield & Low & Low & Low & Low & Low & Low & Low & Low \\
\hline
\end{tabular}

It is used for comparing and ranking risks. Basic Risk Management Facilitation Methods are flow charts, check sheets, process mapping, cause and effect diagrams are the most commonly used simple methods for RA and management ${ }^{26}$

\section{Process mapping ${ }^{27}$}

Which relates critical process parameters and/or critical material attributes and critical product quality to a response surface derived from an experimental data.

\section{Fishbone diagram}

cause and effect diagrams: Represents all aspects which show influence on a critical product quality. Fish Bone diagram contains horizontal line, the end of which points toward the affected product quality. The major influencing factors are then represented as diagonal lines. The influence of the critical process parameters and critical material attributes is then representing as sublines for the diagonal lines. A fishbone diagram is divided into categories like instrumentation, materials, methods, measurements, laboratory climate, and human factors.

Once the risk is assessed it is grouped into three categories:
A. High-risk factors:
B. Potential noise factors:
C. Factors with acceptable ranges:

Steps for risk management includes:

Table 4: Risk Management steps ${ }^{27}$

\begin{tabular}{|c|c|c|}
\hline 1. & Define the Problem & $\begin{array}{l}\text { 1. Effective } \\
\text { 2. Time consuming } \\
\text { 3. They either try to diagram a symptom, or secondary effect }\end{array}$ \\
\hline 2. & Assess Information Needs & $\begin{array}{l}\text { 1. Copious amounts of data are available like video of a process, a printout from a } \\
\text { quality database, or a process walk which act as a starting point. } \\
\text { 2. Decide plan of action for how to collect information to spur brainstorming prior to } \\
\text { gathering to start the fishbone diagram. }\end{array}$ \\
\hline 3. & $\begin{array}{c}\text { Plan Your Fishbone } \\
\text { Diagram }\end{array}$ & $\begin{array}{l}\text { These options are available } \\
\text { 1.On a whiteboard, } \\
\text { 2.With sticky notes pasted to a sheet of butcher paper, } \\
\text { 3.With the use of a computer and projector }\end{array}$ \\
\hline 4. & Gather Information & Any data gaps identified \\
\hline 5. & $\begin{array}{l}\text { Develop Your Cause and } \\
\text { Effect Diagram }\end{array}$ & $\begin{array}{l}\text { Whether real time, or as a second step, the results of the brainstorming session are } \\
\text { organized onto the spines of the fishbone. Note that the process of brainstorming } \\
\text { separately and then adding the ideas, normally on sticky notes, is commonly referred } \\
\text { to as CEDAC, or Cause and Effect Diagram with the Addition of Cards. } \\
\text { Ideas are assigned to the diagram based on the major categories, and then grouped by } \\
\text { similarity. Some of these sub-groups will turn into branches off the main spines as } \\
\text { shown in the earlier graphic (i.e. car broke down->never changed oil). }\end{array}$ \\
\hline
\end{tabular}




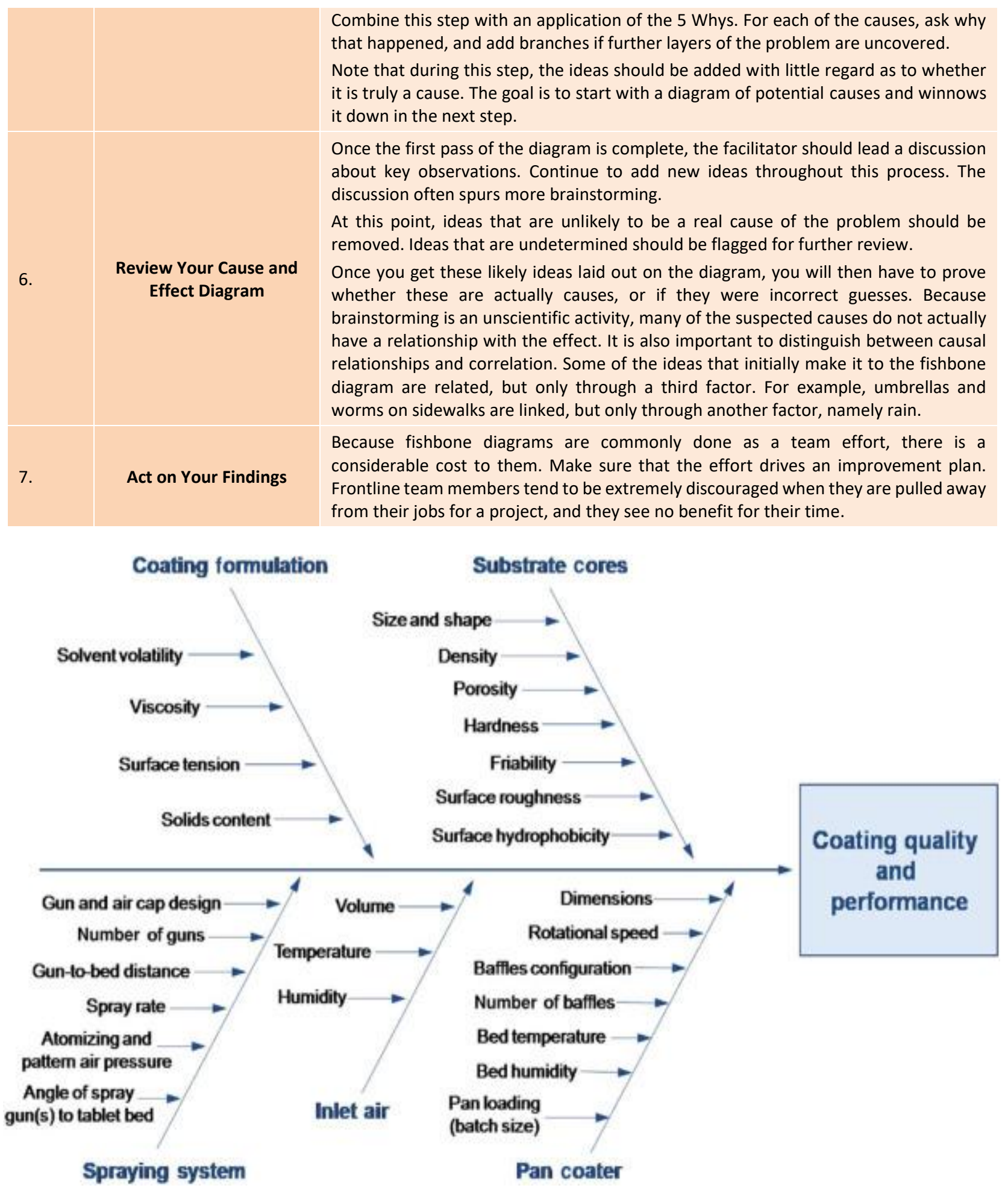

Figure 8: Fishbone diagram for scale up of pan coating process.

Which explain the breaking down the coating process variables into three main types: pan-related, spray-related, and thermodynamic-related factors as shown in above diagram ${ }^{28}$

\section{Critical Process Parameter}

A parameter is critical when a realistic change in that parameter can cause the product to fail to meet the TPQP.
Thus, the first step in classifying parameters is to define the range of interest which we call the potential operating space (POS) which is the region between the maximum and minimum value of interest to the sponsor for each process parameter. Criteria for identifying critical and non-critical parameters are that a parameter is non-critical when there is no trend to failure within the potential operating space and there is no evidence of interactions within the proven acceptable range, which is the range of experimental observations that lead to acceptable quality. 
Table 5: Classification of process parameters

\begin{tabular}{|c|c|c|}
\hline Parameter Type & Definition & Sensitivity \\
\hline $\begin{array}{l}\text { Non-critical process parameter } \\
\text { (non-CPP) }\end{array}$ & Not Critical & $\begin{array}{l}\text { - No failure in Target Product Quality Profile (TPQP) observed } \\
\text { or predicted in the potential operating space (POS), and } \\
\text { No interaction with other parameters in the proven } \\
\text { acceptable range }\end{array}$ \\
\hline $\begin{array}{l}\text { Unclassified process parameters } \\
\text { (UPP) }\end{array}$ & Critically unknown & $\begin{array}{l}\text { - Not established } \\
\text { - The default in the absence of pharmaceutical development }\end{array}$ \\
\hline $\begin{array}{c}\text { Classified process parameters } \\
\text { (CPP) }\end{array}$ & $\begin{array}{l}\text { Critical (control needed } \\
\text { to ensure quality) }\end{array}$ & $\begin{array}{l}\text { - } \text { Failure in target product quality profile(TPQP) observed or } \\
\text { predicted in potential operation space (POS) } \\
\text { Interactions with other parameters in the proven } \\
\text { acceptable range (PAR) }\end{array}$ \\
\hline
\end{tabular}

Some examples of dosage forms with their:

\section{QTPP For IR Tablet}

\begin{tabular}{|c|c|c|}
\hline QTPP & Target & Justification \\
\hline Dosage Design & IR tablet without a score or coating & Immediate release of drug as mentioned on label \\
\hline $\begin{array}{l}\text { Route of } \\
\text { administration }\end{array}$ & Oral & $\begin{array}{l}\text { Pharmaceutical equivalence requirement: same } \\
\text { route of administration }\end{array}$ \\
\hline Dosage strength & $20 \mathrm{mg}$ & $\begin{array}{c}\text { Pharmaceutical equivalence requirement: same } \\
\text { strength }\end{array}$ \\
\hline Pharmaco-kinetics & $\begin{array}{l}\text { Immediate release enabling T max in } 2.5 \\
\text { hr or less; Bioequivalent to RLD }\end{array}$ & $\begin{array}{l}\text { Bioequivalence requirement needed to meet } \\
\text { required rate \& extent of drug absorption }\end{array}$ \\
\hline Container System & Qualified container for IR tablet & $\begin{array}{l}\text { Needed to achieve the target shelf life and ensure } \\
\text { tablet integrity during shipping }\end{array}$ \\
\hline Administration & Similar food effects & High fat meal increases AUC, C max by $8-12 \%$ \\
\hline Stability & At least 24 month & Equivalent to or better than RLD shelf life. \\
\hline $\begin{array}{l}\text { Drug product quality } \\
\text { attributes: }\end{array}$ & $\begin{array}{ll}\text { - } & \text { Description } \\
\text { - } & \text { Identification } \\
\text { - } & \text { Assay } \\
\text { - } & \text { Content Uniformity } \\
\text { - } & \text { Impurity } \\
\text { - } & \text { Dissolution } \\
\text { - } & \text { Microbial limit } \\
\text { - } & \text { Water content }\end{array}$ & $\begin{array}{c}\text { Pharmaceutical equivalence requirement: must } \\
\text { meet the same compendia or other applicable } \\
\text { reference standards (i.e., identity, assay, purity \& } \\
\text { quality). }\end{array}$ \\
\hline
\end{tabular}

\section{QTPP For Solution}

\begin{tabular}{|c|c|c|}
\hline QTPP & Target & Justification \\
\hline Dosage Design & Immediate release formulation & $\begin{array}{l}\text { Pharmaceutical equivalence } \\
\text { requirement as same dosage form }\end{array}$ \\
\hline Route of administration & Oral / External & Immediate release as label claimed \\
\hline Dosage strength & $\mathrm{X} \mathrm{mg}$ & $\begin{array}{l}\text { Pharmaceutical } \\
\text { requirement: same strength Drug } \\
\text { Product }\end{array}$ \\
\hline Pharmaco-kinetics & Not required & \\
\hline $\begin{array}{l}\text { Drug product quality } \\
\text { attributes: }\end{array}$ & $\begin{array}{ll}\text { - } & \text { Description } \\
\text { - } & \text { Identification } \\
\text { - } & \text { Assay drug, preservative } \\
\text { - } & \text { Content Uniformity } \\
\text { - } & \text { Impurity } \\
\text { - } & \text { Dissolution } \\
\text { - } & \text { Microbial limit } \\
\text { - } & \text { Purity \& quality }\end{array}$ & $\begin{array}{l}\text { Pharmaceutical equivalence } \\
\text { requirement: Must meet the same } \\
\text { compendia or other applicable } \\
\text { reference standards }\end{array}$ \\
\hline
\end{tabular}


Container System

\section{Ease Of Storage \& Distribution}

Stability \& Shelf Life

Patient Acceptance \& Patient Compliance
Container (Glass/Plastic/Metal) \& Closure (Plastic/Metal/ Rubber) system should be qualified as suitable for drug product with desired Compatibility \& Stability. Should product from heat, moisture, oxygen, carbon dioxide, light \& microbial attack. Plastic should not allow permeation, leaching, sorption, or any other chemical or physical deformation.

Can be stored at real time storage condition as a normal practice with desired stability \& can be distributed from the manufacturer to end user same as per Reference Product.

Should be stable Hydrolysis, Oxidation, Photodegradation \& Microbial Growth. At least 12-months shelf-life is required at room temperature. At least 28 Days of in-Use Shelf Life is required during routine use of multidose product

Should possess acceptable taste, flavor, odour \& attractable pleasant color most probably as similar with Reference Product. Can be easily administered (pourable \& palatable)/ used/ applied similarly with Reference Product labelling
Required to achieve the target shelf-life and to ensure product integrity during transportation, storage \& during routine-use

Required to handle the product easily with suitable accessibility

Equivalent to or better than Reference Product shelf-life

Required to achieve the desired patient acceptability \& suitable compliance

\section{QTPP For Suspension}

\begin{tabular}{|c|c|}
\hline QTPP & Target \\
\hline Dosage Design & Immediate release formulation \\
\hline Route of administration & Oral \\
\hline Dosage strength & $\mathrm{X} \mathrm{mg/ml}$ \\
\hline Pharmaco-kinetics & Rate of absorption, Extent of absorption \\
\hline $\begin{array}{l}\text { Drug product quality } \\
\text { attributes: }\end{array}$ & $\begin{array}{ll}\text { - } & \text { Description } \\
\text { - } & \text { Identification } \\
\text { - } & \text { Content Uniformity } \\
\text { - } & \text { Impurity } \\
\text { - } & \text { Dissolution } \\
\text { - } & \text { Antioxidant content } \\
\text { - } & \text { PSD } \\
\text { - } & \text { pH } \\
\text { - } & \text { Viscosity } \\
\text { - } & \text { Specific Gravity } \\
\text { - } & \text { Leachable/ Extractable } \\
\text { - } & \text { Microbial limit } \\
\text { - } & \text { Purity \& quality }\end{array}$ \\
\hline Container System & $\begin{array}{c}\text { Container (Glass/Plastic/Metal) \& Closure } \\
\text { (Plastic/Metal/Rubber) system should be qualified as } \\
\text { suitable for drug product with desired Compatibility \& } \\
\text { Stability. }\end{array}$ \\
\hline $\begin{array}{c}\text { Ease Of Storage } \& \\
\text { Distribution }\end{array}$ & $\begin{array}{l}\text { Can be stored at real time storage condition as a normal } \\
\text { practice with desired stability against sedimentation, } \\
\text { caking, hydrolysis, oxidation, photo degradation, } \\
\text { microbial growth with at least } 28 \text { days of use shelf life }\end{array}$ \\
\hline Stability \& Shelf Life & $\begin{array}{c}\text { Should be stable Hydrolysis, Oxidation, } \\
\text { Photodegradation \& Microbial Growth. At least 12- } \\
\text { months shelf-life is required at room temperature. At } \\
\text { least } 28 \text { Days of in-Use Shelf Life is required during } \\
\text { routine use of multidose product }\end{array}$ \\
\hline $\begin{array}{l}\text { Patient Acceptance \& } \\
\text { Patient Compliance }\end{array}$ & $\begin{array}{c}\text { Should possess acceptable taste, flavor, odour \& } \\
\text { attractable pleasant color. Can be easily redispersed, } \\
\text { administered (pourable \& palatable)/ used/ applied } \\
\text { similarly with Reference Product labelling }\end{array}$ \\
\hline
\end{tabular}

Pharmaceutical equivalence requirement as same dosage form

Immediate release as label claimed

Pharmaceutical equivalence requirement Limits of 80-125 With reference standard

Acceptable limits of specification

Required to achieve the target shelf-life and to ensure product integrity during transportation, storage \& during routine-use

Required to handle the product easily with suitable accessibility

Equivalent to or better than Reference Product shelf-life

Required to achieve the desired patient acceptability \& suitable compliance 


\title{
QTPP For nanoparticles (SLN)
}

\begin{tabular}{|c|c|c|c|}
\hline \multicolumn{2}{|c|}{ Quality Attributes of the Drug Product } & Target & Justification \\
\hline \multirow{2}{*}{ Physical Attributes } & Appearance & $\begin{array}{c}\text { Color should be acceptable, } \\
\text { odour and taste should be } \\
\text { masked }\end{array}$ & $\begin{array}{l}\text { Color, odor and appearance are not } \\
\text { directly linked to safety and efficacy. } \\
\text { Therefore, they are not critical. }\end{array}$ \\
\hline & Size & $\begin{array}{c}\text { Size of the SLN should be in } \\
\text { Nanometer range }\end{array}$ & $\begin{array}{l}\text { Small size of the SLN is responsible for } \\
\text { its prolonged release of action. } \\
\text { Therefore, it was considered as CQA. }\end{array}$ \\
\hline \multicolumn{2}{|c|}{ \% Entrapment Efficiency } & $70-90 \%$ & $\begin{array}{l}\text { \%EE is critical while adjusting the dose } \\
\text { of the formulation }\end{array}$ \\
\hline
\end{tabular}

\section{For Soft gelatin capsule}

\begin{tabular}{|c|c|c|}
\hline QTPP Element & Target & Justification \\
\hline Dosage form & Soft gelatin capsule & $\begin{array}{c}\text { Pharmaceutical equivalence requirement: } \\
\text { same dosage form }\end{array}$ \\
\hline $\begin{array}{c}\text { Dosage design } \\
\text { Route of }\end{array}$ & Immediate release / modified release formulation & $\begin{array}{c}\text { Immediate release design needed to meet } \\
\text { label claims }\end{array}$ \\
\hline administration & Oral & Pharmaceutical equivalence requirement: \\
sosage strength & $\mathrm{x} \mathrm{mg}$ & Pharmate of administration
\end{tabular}

Drug product quality attributes:

\section{1. description \\ 2. assay \\ 3. uniformity \\ 4. impurity \\ 5. dissolution \\ 6. microbial limit \\ 7. water content \\ 8. residual solvents}

\begin{abstract}
Pharmaceutical equivalence requirement: must meet the same compendia or other applicable reference standards (i.e., identity, assay, purity \& quality).
\end{abstract}

\section{Primary packaging}

Pharmaco-kinetics

Ease of storage $\&$

distribution

Stability \& shelf life

Patient acceptance \&patient compliance
Plastic container \& closure/ metal blister system should be qualified as suitable for drug product with desired appropriate compatibility \& stability. should protect product from heat, moisture, oxygen, light \& microbial attack.

Fasting bio-equivalence study $90 \%$ confidence interval of the pk parameters, auc $0-t$, auc $0-\infty$ and $\mathrm{cmax}$, should fall within bioequivalence limits of $80-125$ with reference product

Can be stored at real time storage condition as a normal practice with desired stability \& can be distributed from the manufacturer to end user same as per reference product.

Should be stable against hydrolysis, oxidation, photo degradation \& microbial growth. at least 24-month shelf-life is required at room temperature

Should be suitably flavored \& colored for possessing acceptable taste (in case of soluble/ dispersible/ effervescent tablet) similar with reference product.

can be easily administered/used similar with reference product labeling
Required to achieve the target shelf-life and to ensure product integrity during transportation, storage \& during routine-use

Bioequivalence requirement needed to meet required rate $\&$ extent of drug absorption

Required to handle the product easily with suitable accessibility

Equivalent to or better than reference product shelf-life

Required to achieve the desired patient acceptability \&suitable compliance

\section{Process Control Strategy ${ }^{29}$}

Many Control Strategy elements are developed via risk assessments: CQA/CPP, Raw Material, Components, Specifications. Control Strategy is the final outcome of process development
("Process Design" if using FDA terminology). A Control Strategy is not a "point-in-time" activity, but rather should evolve as knowledge increases. A Control Strategy is constituted of many parts, many of which are developed/written at different points in time throughout 
process development.

Process validation:

Which include three stages

\section{Stage 1}

Process Design, which include identification of critical process parameter, determination of control strategy.

Control strategy includes:

- Quality attribute assessment

- Material specification

- Drug specification

- $\quad$ Process parameter assessment

- In-process control

- Manufacturing documentation, narrative

- Component specification

- $\quad$ Packaging specifications

- $\quad$ Storage stability

Stage 2

Process qualification; which includes equipment, utility, facility qualification, process performance qualification. Process performance qualification is a dynamic part of the validation concept

- Provides proof the process is well controlled

- Establishes an initial baseline for future process evaluation

\section{Stage 3}

Process Monitoring, which include critical process parameters, and monitoring programs.

\section{Lifecycle Management}

Throughout the product lifecycle, the manufacturing process performance will be monitored to ensure that it is working as anticipated to deliver the product with desired quality attributes. Process stability and process capability will be evaluated. If any unexpected process variability is detected, appropriate actions will be taken to correct, anticipate, and prevent future problems so that the process remains in control.

\section{Applications of Quality by design ${ }^{29,} 30$}

Quality by design (QbD)-a comprehensive systematic approach to pharmaceutical development and manufacturing.

Advancement in the pharmaceutical development and manufacturing by Qbd can be explained against traditional approach.

\section{In Pharmaceutical Development}

To design a quality product and a manufacturing process to consistently deliver the intended performance of the Product.

\section{Benefits of Implementing QbD for FDA:}

- Enhances scientific foundation for review

- Provides for better coordination across review, compliance and inspection

- Improves information in regulatory submissions

- Provides for better consistency

- Improves quality of review (establishing a QMS for CMC)

- Provides for more flexibility in decision making

- Ensures decisions made on science and not on empirical information

- Involves various disciplines in decision making

- Uses resources to address higher risks

\section{Benefits to Industry}

- Ensures better design of products with less problems in manufacturing

- Reduces number of manufacturing supplements required for post market changes -rely on process and risk understanding and risk mitigation

- Allows for implementation of new technology to improve manufacturing without regulatory scrutiny

- Allows for possible reduction in overall costs of manufacturing -less waste

- Ensures less hassle during review -reduced deficiencies -quicker approvals

- Improves interaction with FDA -deal on a science level instead of on a process level

- Allows for continuous improvements in products and manufacturing process.

\section{Pharmaceutical Development}

- Widely used in pharmaceutical development and manufacturing

\section{CONCLUSION}

$\mathrm{QbD}$ has gain significance in the vicinity of pharmaceutical processes like drug development, formulations development, analytical method and biopharmaceuticals. Qbd also support to develop a reliable method as per ICH Q8 and Q9 assurance to constantly reproducible data meeting predefined criteria for high quality and safety. This new QbD process offers the opportunity for much better regulatory flexibility in the future by risk assessment and risk management through various methods.

\section{REFERENCES}

1. learnaboutgmp.com

2. Sangshettia JN, Deshpandea M, Zaheera Z, Shinde D B, Arote $\mathrm{R}$ : Quality by design approach: Regulatory need. Arabian Journal of Chemistry 5, 2017, S3412-S3425. 
3. Shashi A, Jain SK and Pandey M: In-vitro evaluation of antilthiatic activity of seeds of Dolichos biflorus and roots of Asparagus racemosus. International Journal of Plant Sciences 1, 2008, 67-71.

4. Steven L, Jim A: Elements of Quality by Design in Development and Scale-Up of Freeze-Dried Parenterals . BioPharm International 21, 2008, 1-8.

5. U. S. Food and Drug Administration. Guidance for Industry: Q8 (2) Pharmaceutical Development. 2009.

6. USP 34-NF 29 (United States Pharmacopeial Convention). Chapter 1078. Good manufacturing practice for bulk pharmaceutical excipients. Rockville, MD: USP, 2011, pp. $1415-1420$

7. USP 34-NF 29 (United States Pharmacopeial Convention). USP and NF Excipients, Listed by Category. Rockville, MD: USP, 2011, pp. 583-595.

8. U. S. Food and Drug Administration. Inactive Ingredient Search for Approved Drug Products.http://www.accessdata.fda.gov/scripts/cder/iig/i ndex.cfm, Accessed 13 Aug 2013.

9. Kannissery P, Tahir M, Naseem A. Charoo, Shahid H. Ansari, Ali J. Pharmaceutical product development: A quality by design approach. Int J Pharm Investig. 6(3), 2016, 129-138.

10. Bindhu M. R. Quality by Design: A Brief Introduction. J Pharmacovigilance 3, 2015, 142.

11. Nazzal S, Nutan M, Palamakula A, Shah R, Zaghloul AA, Khan MA. Optimization of a self-nanoemulsified tablet dosage form of ubiquinone using response surface methodology: effect of formulation ingredients. Int J Pharm. 240, 2002, 103-14.

12. Awotwe-Otoo D, Agarabi C, Wu GK, Casey E, Read E, Lute S, et al. Quality by design: impact of formulation variables and their interactions on quality attributes of a lyophilized monoclonal antibody. Int J Pharm. 438(1-2), 2012, 167-75.

13. Scypinski S., Roberts D., Oates M., Etse J. Pharmaceutical research and manufacturers association acceptable analytical practice for analytical method transfer.Pharmaceutical Technology 26(3), 2002, 84-88.

14. Raman N. V. V. S. S., Reddy U M, Bapatu H R. Analytical Quality by Design Approach to Test Method Development and Validation in Drug Substance Manufacturing .Journal of Chemistry 1, 2015, 1-8.

15. Vemuri P K, Gupta N V. A Review on quality by design approach (QBD) for Pharmaceuticals. International Journal of Drug Development and Research 7 (1), 2015, 52-60.
16. Ranga S, Jaimini M, Sharma S K, Chauhan B S, Kumar A. A review on design of experiment. International Journal of Research and Reviews in Pharmacy and Applied science 3(6), 2013, 867-82.

17. www.pda.org

18. International Conference on Harmonization (ICH) and FDA Guidance for Industry, Q8(R2) Pharmaceutical Development, Nov. 2009.

19. $\mathrm{ICH}$ and FDA Guidance for Industry, Q9 Quality Risk Management, June 2006.

20. Mogal V, Dusane J, Borase $P$, Thakare $P$, Kshirsagar S. A review on quality by design. Pharmaceutical and Biological Evaluations 3(3), 2016, 313-319.

21. Leuenberger $H$, Puchkov $M$, Krausbauer $E$, Betz $G$, manufacturing pharmaceutical granules, Is the granulation end-point a myth, Powder Technology 189, 2009, 141-148.

22. Miller CE, Chemometrics and NIR: A match made in heaven, Am. Pharm. Rev. Food and Drug Administration CDER, Guidance for industry, Q8 pharmaceutical development 2(12), 2006, 41-48, 2006.

23. Nasr M. Risk-based CMC review paradigm, Advisory committee for pharmaceutical science meeting, 2004.

24. Kumar V P, Gupta N V. A Review on quality by design approach (QBD) for Pharmaceuticals. Int. J. Drug Dev. \& Res 7 (1), 2015, 35-44.

25. US Food and Drug Administration. Guidance for industry: Q8(R2) pharmaceutical development. US Department of Health and Human Service (FDA, Rockville, MD, 2009.

26. ICH Q9: Quality Risk Management - an update 14 May 2014.

27. Fahmy R, Kona R, Dandu R, Xie W, Claycamp G, Hoag SW. Quality by design I: Application of failure mode effect analysis (FMEA) and Plackett-Burman design of experiments in the identification of "main factors" in the formulation and process design space for roller-compacted ciprofloxacin hydrochloride immediate-release tablet. AAPS PharmSciTech. 13(4), 2012, 1243-1254.

28. Emami J. In vitro - in vivo correlation: From theory to applications. J Pharm Pharm Sci. 9, 2006, 169-89

29. Anjali M. Agrawal, Preetanshu Pandey. Scale Up of Pan Coating Process Using Quality by Design Principles. Journal of Pharmaceutical Sciences 104(11), 2015, 3589-3611.

30. Kannissery P, Tahir MA, Naseem A. C, Ansari S H, Ali J. Pharmaceutical product development: A quality by design approach, Int J Pharm Investig. 6(3), 2016, 129-138.

31. A Review on quality by design approach (QBD) for Pharmaceuticals, Vemuri Pavan Kumar, N. Vishal Gupta, Int. J. Drug Dev. \& Res. 7 (1), 2015, 35-44.

\section{Source of Support: None declared.}

Conflict of Interest: None declared.

For any question relates to this article, please reach us at: editor@globalresearchonline.net

New manuscripts for publication can be submitted at: submit@globalresearchonline.net and submit_ijpsrr@rediffmail.com 